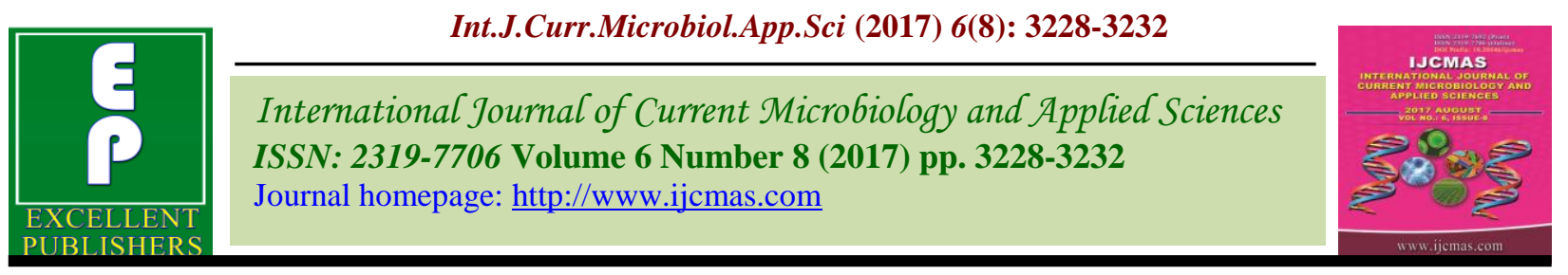

Original Research Article

https://doi.org/10.20546/ijcmas.2017.608.385

\title{
Study on Genetic Variability, Heritability and Genetic Advance in Dolichos Bean (Lablab purpureus L.) Genotypes
}

\author{
Radhelal Dewangan*, Vijay Bahadur, Praveen Choyal, Ramesh, Shatis Xaxa, \\ Vipul Pratap Singh, Shubham Sachan and Anita Kerketta
}

\author{
Department of Horticulture, SHUATS, Allahabad, U.P, India \\ *Corresponding author
}

A B S T R A C T

\begin{tabular}{|c|c|}
\hline $\begin{array}{l}\text { Key w o r d s } \\
\text { Dolichos bean, } \\
\text { Genetic } \\
\text { variability, } \\
\text { Heritability and } \\
\text { Genetic advance. }\end{array}$ & $\begin{array}{l}\text { The present investigation was carried out to study the genetic variability, } \\
\text { heritability and genetic advance for } 17 \text { traits in dolichos bean. The } \\
\text { experimental material comprised of } 38 \text { genotypes of dolichos bean (Lablab } \\
\text { purpureus L.). The highest value of genotypic coefficient of variation (GCV) } \\
\text { was recorded for inflorescence length }(28.10 \%) \text {. The highest value of }\end{array}$ \\
\hline Article Info & length $(28.16 \%)$. The highest heritability estimate was observed for days to \\
\hline $\begin{array}{l}\text { Accepted: } \\
\text { 26 June } 2017 \\
\text { Available Online: } \\
10 \text { August } 2017\end{array}$ & $\begin{array}{l}50 \% \text { flowering }(99.95 \%) \text {. The highest genetic advance as percent of mean } \\
\text { observed for inflorescence length (57.76). Hence selection will be effective for } \\
\text { these traits. }\end{array}$ \\
\hline
\end{tabular}

\section{Introduction}

It is known as poor's man bean (Ismunandji and Arsyad, 1990). It is commonly called as Hyacinth bean, bonavist bean, Indian bean, field bean, Egyptian bean, lablab bean, Avare in Kannada. It belongs to the family Fabaceae, sub family Faboideae, tribe phaseoleae and sub tribe phaseolineae. It is one of the most ancient crops known for its food and fodder value. Dolichos bean has chromosome number $2 \mathrm{n}=2 \mathrm{x}=22$. Dolichos bean (Lablab purpureus L.) is an important leguminous vegetable crop grown throughout the country and distributed in Madhya Pradesh, Maharastra, Andhra Pradesh, Tamil Nadu and North Eastern states. India is world's largest producer of vegetables next to China with an annual production around
166.60 (million MT) from 9.57 (mha) of land with the productivity of $17.3 \mathrm{MT} / \mathrm{ha}$ (National Horticulture Mission, 2016).

It is sensitive to photoperiods and both short day and long day types are available and recently someday neutral types are also reported. Field bean is a drought tolerant crop and it is an excellent crop to be grown in dry lands with limited rainfall. It cannot stand water logging condition. The characters for which variability is present should be highly heritable for the success of crop improvement programme as progress due to selection depends on heritability, selection intensity and genetic advance of the character. Heritability and genetic advance estimates for 
different targeted traits help the breeder to apply appropriate breeding methodology in the crop improvement programme.

\section{Materials and Methods}

The experiment was carried out at the Horticulture Research Farm, Department of Horticulture, Naini Agricultural Institute, Sam Higginbottom University of Agriculture, Technology and Sciences, Allahabad U.P. The experiment was conducted in Randomized Block Design having thirty eight genotypes collected from different part of Chhattisgarh in three replications. The allocation of treatments of the individual plots using random number in each replications with spacing $1.5 \times 1 \mathrm{~m}$ row to row and plant to plant respectively. Five plants from each replication were taken for recording observation on 17 characters viz. days to first flowering, days to $50 \%$ flowering, inflorescence length, number of flowers per inflorescence, number of pods per inflorescence, days to first green pod harvest, days to last pod harvest, number of green pod pickings, pod length, pod width, pod weight, number of seeds per pod, vine length, 100 seed weight, green pod yield per plant, green pod yield per plot, green pod yield per hectare.

\section{Results and Discussion}

A clear understanding of the extent of variability prevailing for each trait in germplasm is essential for the improvement of character through selection. In hybridization programme, selection of genetically diverse parent is important to get wide range of recombinants. The analysis of variance (ANOVA) revealed significant differences between genotypes indicating presence of sufficient amount of variability in all the characters studied. These results are similar with the findings of Chattopadyay and Dutta (2010), Upadhyay and Mehta (2010), Islam et al., (2011), Magalingam et al., (2013), Verma et al., (2014), Singh et al., (2015) and Kujur et al., (2017).

Table.1 Source of Genotypes of Dolichos Bean

\begin{tabular}{clcl}
\hline S.No. & \multicolumn{1}{c}{ Genotypes } & No. of genotypes & \multicolumn{1}{c}{ Source of Genotypes } \\
\hline 1. & CG 1, CG 2,CG 5,CG 6 & 4 & Lundra Surguja CG \\
2. & CG 7,CG 8,CG 9. & 3 & Ambikapur Surguja CG \\
3. & CG 3,CG 4. & 2 & Bilha, Bilashpur, CG \\
4. & CG 10,CG 11,CG 12,CG & 7 & Udaipur Surguja CG \\
& 13,CG 14,CG 15,CG 16. & 2 & Udagi Surajpur CG \\
5 & CG. 17,CG 18. & 2 & Lailunga Raigarh, CG \\
6 & CG 19, CG 28, & Ramanujnagar Surajpur CG \\
7 & CG 20, CG 21, CG 22, & 3 & Bhaiyathan Surajpur CG \\
8 & CG 23. & 1 & Pathalgaon Jashpur CG \\
9 & CG 24,CG 25,CG 26,CG & 4 & Reewagahan, Rajnandgaon CG \\
& 27. & & \\
10 & CG 29, CG 30,CG 31,CG & 8 & IIVR Varanasi,U.P. \\
& 32,CG 33,CG 34,CG & & IARI, Delhi \\
\hline
\end{tabular}


Table.2 Genetic parameter of yield and its attributing traits of dolichos bean

\begin{tabular}{|c|c|c|c|c|c|c|c|c|c|c|}
\hline \multirow{2}{*}{ S.N. } & \multirow{2}{*}{ Characters } & \multicolumn{2}{|c|}{ Range } & \multirow{2}{*}{ Mean } & \multicolumn{3}{|c|}{ Coefficient of variance } & \multirow{2}{*}{$\mathbf{h}^{2}(\%)$} & \multirow{2}{*}{$\begin{array}{l}\text { Genetic } \\
\text { advance }\end{array}$} & \multirow{2}{*}{$\begin{array}{c}\text { Genetic } \\
\text { advance as a } \% \\
\text { of mean }\end{array}$} \\
\hline & & Min. & Max. & & GCV & PCV & ECV & & & \\
\hline 1 & Days of First Flowering & 93.41 & 46.20 & 116.67 & 15.89 & 15.89 & 0.44 & 99.93 & 30.56 & 32.72 \\
\hline 2 & Days of $50 \%$ Flowering & 97.01 & 49.80 & 120.47 & 15.31 & 15.31 & 0.37 & 99.95 & 30.58 & 31.52 \\
\hline 3 & Inflorescence Length (cm.) & 19.14 & 7.08 & 28.40 & 28.10 & 28.16 & 1.85 & 99.92 & 11.06 & 57.76 \\
\hline 4 & Flowers/Inflorescence & 13.52 & 9.87 & 20.00 & 19.18 & 19.60 & 4.07 & 95.68 & 5.22 & 38.64 \\
\hline 5 & Pod Formations/Inflorescence & 6.92 & 4.33 & 10.93 & 20.72 & 21.33 & 5.07 & 94.36 & 2.87 & 41.47 \\
\hline 6 & Days to First green Pod harvest & 109.00 & 60.67 & 133.67 & 13.74 & 13.78 & 0.96 & 99.51 & 30.78 & 28.24 \\
\hline 7 & Days of Last Green Pod harvest & 194.53 & 175.67 & 206.33 & 4.61 & 4.65 & 0.68 & 97.88 & 18.26 & 9.39 \\
\hline 8 & Number of Green Pod Picking & 6.08 & 5.00 & 7.67 & 7.43 & 11.64 & 8.97 & 40.70 & 0.59 & 9.76 \\
\hline 9 & Pod Length (cm.) & 9.42 & 3.85 & 13.02 & 22.14 & 22.44 & 3.69 & 97.27 & 4.24 & 44.98 \\
\hline 10 & Pod Width $(\mathrm{cm})$ & 1.96 & 1.37 & 4.22 & 26.46 & 26.99 & 5.31 & 96.12 & 1.05 & 53.44 \\
\hline 11 & Pod Weight (g) & 7.24 & 2.47 & 11.36 & 25.09 & 26.16 & 7.41 & 91.96 & 3.59 & 49.56 \\
\hline 12 & Number of Seeds/ Pod & 5.12 & 3.11 & 6.31 & 12.05 & 14.13 & 7.38 & 72.71 & 1.08 & 21.16 \\
\hline 13 & Vine Length (m) & 5.81 & 4.47 & 8.35 & 14.90 & 15.88 & 5.49 & 88.02 & 1.67 & 28.79 \\
\hline 14 & Seed Index (g) & 32.26 & 20.57 & 51.33 & 27.09 & 27.25 & 2.91 & 98.86 & 17.90 & 55.49 \\
\hline 15 & Green Pod Yield Per Plant (kg) & 1.71 & 0.93 & 2.24 & 17.80 & 18.82 & 6.14 & 89.37 & 0.59 & 34.66 \\
\hline 16 & Green Pod Yield Per Plot (kg) & 10.28 & 5.56 & 13.42 & 17.80 & 18.82 & 6.14 & 89.37 & 3.56 & 34.66 \\
\hline 17 & Pod Yield (q/ha) & 114.20 & 61.77 & 149.11 & 17.79 & 18.83 & 6.14 & 89.34 & 39.57 & 34.65 \\
\hline
\end{tabular}


The highest value of genotypic coefficient of variation (GCV) was recorded for inflorescence length $(28.10 \%)$, followed by 100 seed weight (27.09\%), pod width (26.46\%), pod weight $(25.09 \%)$, pod length (22.14\%), number of pods per inflorescence $(20.72 \%)$, number of flower per inflorescence $(19.18 \%)$, green pod yield per plant $(17.80 \%)$, green pod yield per plot $(17.80 \%)$, green pod yield per hectare $(17.79 \%)$, days to first flowering $(15.89 \%)$, days to $50 \%$ flowering (15.31\%), vine length (14.90\%), days to first green pod harvest (13.74\%), no. of seeds per pods $(12.05 \%)$, number of green pod picking (7.43\%), and lowest genotypic coefficient of variation was recorded for days to last pod harvest $(4.61 \%)$. The Similar results were noticed by Kujur et al., (2017) for all characters, Sharma et al., (2014) for days to first flowering, days to $50 \%$ flowering, pod formation per inflorescence, pod length (cm), Varma et al., (2014) for days to first flowering, days to $50 \%$ flowering, pod formation per inflorescence, days to $1^{\text {st }}$ pod harvesting, pod length $(\mathrm{cm})$ and pod width $(\mathrm{cm})$, days to last pod harvesting.

The highest value of phenotypic coefficient of variation (PCV) was recorded for inflorescence length (28.16\%), followed by 100 seed weight $(27.25 \%)$, pod width (26.99\%), pod weight (256.16\%), pod length $(22.44 \%)$, number of pods per inflorescence $(21.33 \%)$, number of flower per inflorescence $(19.60 \%)$, green pod yield per hectare $(18.83 \%)$, green pod yield per plant $(18.82 \%)$, green pod yield per plot $(18.82 \%)$, days to first flowering (15.89\%), vine length $(15.88 \%)$, days to $50 \%$ flowering $(15.31 \%)$, no. of seeds per pods $(14.13 \%)$,days to first green pod harvest (13.78\%), number of green pod picking (11.64\%), and lowest phenotypic coefficient of variation was recorded for days to last pod harvest $(4.65 \%)$. The Similar results were noticed by Kujur et al., (2017) for all characters, Sharma et al., (2014) for days to first flowering, days to $50 \%$ flowering, pod formation per inflorescence, pod length $(\mathrm{cm})$ and pod width $(\mathrm{cm})$, Varma et al., (2014) for days to first flowering, days to $50 \%$ flowering, pod formation per inflorescence, days to $1^{\text {st }}$ pod harvesting, pod length $(\mathrm{cm})$ and pod width $(\mathrm{cm})$, days to last pod harvesting, Sharma et al., (2014) days to first flowering, days to $50 \%$ flowering, pod length and days to $1^{\text {st }}$ pod harvesting, green pod yield/plant.

Highest heritability estimate was observed for days to $50 \%$ flowering $(99.95 \%)$ followed by days to first flowering (99.93\%), inflorescence length $(99.92 \%)$, days to first green pod harvest (99.51\%), 100 seed weight $(98.86 \%)$, days to last green pod harvest (97.88\%), pod length (97.29\%), pod width (96.12\%), flower per inflorescence (95.68\%), number of pod formation per inflorescence (94.36\%), pod weight $(91.96 \%)$, pod yield per plant $(89.37 \%)$, pod yield per plot $(89.37 \%)$, pod yield per ha. (89.34\%), plant vine length $(88.02 \%)$, number of seeds per pod $(72.71 \%)$. While minimum heritability was observed in number of pod picking (40.70\%). The Similar results were noticed by Kujur et al., (2017) for all characters, Varma et al., (2014) for days to first flowering, days to $50 \%$ flowering, pod formation per inflorescence, days to $1^{\text {st }}$ pod harvesting, pod length $(\mathrm{cm})$ and pod width $(\mathrm{cm})$, days to last pod harvesting.

On the other hand highest genetic advance as percent of mean observed for inflorescence length (57.76), followed by 100 seed weight (55.49), pod width (53.44), pod weight (49.56), pod length (44.98), number of pods per inflorescence (41.47), number of flower per inflorescence (38.64), green pod yield per plant (34.66), green pod yield per plot (34.66), pod yield per ha. (34.65), days to first flowering (32.72), days to $50 \%$ flowering (31.52), vine length (28.79), days to first 
green pod harvest (28.24), seed/pod (21.16) and number of green pod picking (9.76). The lowest genetic advance as percent of mean was observed for days to last green pod harvest (9.39). The Similar results were noticed by Kujur et al., (2017) for all characters, Varma et al., (2014) for days to 50 $\%$ flowering, number of pods per inflorescence, pod length $(\mathrm{cm}), 100$ seed weight, Sharma et al., (2014) for seed/pods, Magalingam et al., (2014) for pod length (cm) and pod width $(\mathrm{cm})$, pod weight $(\mathrm{g})$.

\section{Acknowledgement}

Authors are sincerely Thankful to Dr. Vijay Bahadur Associate Prof., Department of Horticulture Naini agricultural institute SHUATS Allahabad (U.P). and Thanks to my friends Praveen Choyal, Ramesh, Shatis Xaxa, Mithlesh Gupta.

\section{References}

Chattopadyay, A. and Dutta, S. 2010. Characterization and identification of selection indices of pole type dolichos bean. Veg. Crops Res. Bull., 73: 33-45.

Islam, M.S., Rahman, M.M. and Mian, M.A.K. 2011. Genetic variability, heritability and correlation study in hyacinth bean. Bang. J. Agril. Res., 36(2): 351-356.

Ismunadji, M. and Arsyad, D.M. 1990. Lablab bean: An unexploited potential food legume. Paper presented to the Training / Workshop on improvement of unexploited and potential food legumes in Asia, $27^{\text {th }}$ October to $3^{\text {rd }}$ November 1990 ,
Bogor, Indonesia.

Kujur, P.K., Bahadur, V., and Pankaj, P. 2017. Study on Genetic variability, heritability and genetic advance in Dolichos bean (Lablab purpureus L.) genotypes. Trends in Biosci., 10(13): 2418-2421.

Magalingam, V., Yassin, M. and Kumar, S.R. 2013. Genetic variability and character association in dolichos bean. SAARC J. Agri., 11(2): 161-171.

NHB. 2016. Indian Horticulture Database, 178185.

Savitha, B.N. 2008. Characterization of avare (Lablab purpureus L.) Sweet) local collections for genetic variability. M. Sc. (Agri.) Thesis, Uni. Agri. Sci., Bangalore (India).

Sharma, D.P., Dehariya, N.K. and Tiwari, A. 2014. Genetic variability, correlation and path cofficiant analysis in Dolichus bean (Lablab purpureus L.). Int. J. Basic and Appl. Agri. Res. Technol., 12(4): 193199.

Singh, S., Singh, P.K., Singh, D.R., Pandey, V.B. and Srivastava, R.C. 2015. Genetic variability and character association study in Dolichos bean (Lablab purpureus L.). Indian J. Horticulture, 72(3): 343-346.

Upadhyay, D. and Mehta, N. 2010. Biometrical studies in Dolichos Bean (Dolichos lablab L.) for Chhattisgarh Plains. Res. J. Agril. Sci., 1(4): 441-447.

Verma, A.K., Jyothi, K.U., and Rao, A.V.D. 2014. Genetic variability, Heritability and genetic advance studies in Dolichos bean (Lablab purpureus L.) genotypes. Electronic J. Plant Breeding, 5(2): 272276.

\section{How to cite this article:}

Radhelal Dewangan, Vijay Bahadur, Praveen Choyal, Ramesh, Shatis Xaxa, Vipul Pratap Singh, Shubham Sachan and Anita Kerketta. 2017. Study on Genetic Variability, Heritability and Genetic Advance in Dolichos Bean (Lablab purpureus L.) Genotypes. Int.J.Curr.Microbiol.App.Sci. 6(8): 3228-3232. doi: https://doi.org/10.20546/ijcmas.2017.608.385 